\title{
Changing Myopic View on Outsourcing Decision in the Manufacturing Industry: A Case from Malaysia
}

\author{
Shankar Chelliah* \\ School of Management, Universiti Sains Malaysia, \\ 11800 USM, Penang,Malaysia \\ E-mail: shankar@usm.my \\ Jenny Teoh Aui Meng \\ Open University of Malaysia,Seberang Jaya, Penang, Malaysia \\ E-mail: jennyteoh99@yahoo.com \\ Jayaraman Munusamy \\ Centre of Postgraduate Studies, LimKokWing University, \\ 63000 Cyberjaya, Selangor, Malaysia. \\ E-mail: dr.jayaraman@limkokwing.edu.my
}

\begin{abstract}
The purpose of this study is to understand the factors influencing outsourcing decision in the manufacturing industry. Existing literature reveals that manufacturing industry face with challenges in the competitive environment with expectation to produce products at the lowest cost possible yet meet customer specification without affecting the quality and delivery schedules. Thus, outsourcing has become one of the alternative opportunities among the manufacturing firms. The theoretical framework is developed to understand four components namely operating cost, new product development, internal resources and technology, and as well as management competency as the determinants of outsourcing decision. This is a quantitative research and survey instrument was used. The questionnaire was distributed to 150 firms in Northern region of Malaysia with a response rate of $45 \%$. The data was analyzed using regression to test the hypotheses. The findings showed that capital investment, latest technology and high efficiency becomes the key determinants for outsourcing decision among the manufacturing firms. It poses some implications for managers and policy makers.
\end{abstract}

Keywords: operating cost, new product development, internal resources and technology, management competency

\section{Introduction}

Over the past 25 years, transaction cost economics (TCE) has emerged as a predominant theoretical explanation of outsourcing. In the situations of uncertainty, it is more efficient for an organization to perform the transaction in house than to incur the probative cost of turning to the market. The transaction cost theory has received great empirical support in explaining outsourcing decisions (Joskow, 1988; Lyons, 1995; Masten, 1984; Monteverde \& Teece, 1982; Murray et al., 1995; Walker \& Weber, 1984). The study of the outsourcing phenomenon and its determinants has therefore traditionally focused more on economic approaches. There are other aspects other than economic factors, such as organizational factors

\footnotetext{
*Corresponding Author
} 
that would impactful towards outsourcing decision.

Outsourcing means engage outsiders to handle some business functions that reduce the company's expenditure and save money. It is not a new phenomenon. For decades, jobs have been migrated from other part of the countries namely, American and European countries as well as other countries worldwide, to global service providers, primarily India, China, Singapore and Malaysia, due to lower operating cost. The recent wave of outsourcing affected a different mix of jobs, at different wage levels. It has confined only to a small industry but cut across all industrial sections in new geographic area rapidly. Not many companies fully understand the benefits of outsourcing. It is true that outsourcing can save money, but that is not the only (or even the most important) reason to do it. As many companies discovered during the outsourcing "mania" of the early 1990s, outsourcing brought mix results to companies that choose outsourcing. However, outsourcing can provide a number of long terms benefits: lower operating cost, improve competitiveness, reduce in capital investment, shift resources to focus on core functions, generate demand for new growth and market segment, access to world class capability, sharing risks and make capital funds available for core business investment. In Malaysia, there were many companies looking into outsourcing opportunity to reduce cost, to overcome internal limitations and achieve lower cost of operation especially in the current economic recession. In view of this, the objective of this research is to understand the factors influencing companies in Malaysia in the outsourcing decision.

\section{Review of Literature and Hypothesis Development}

\subsection{What is Outsourcing}

The term 'outsourcing' from literature has different interpretations recent years. Therefore, it will be good to review the various views on the meaning of outsourcing as shown in Table 1. Most authors agree that outsourcing means exploring business activities outside the firm. Thus, we can classify the definitions into three types: (a) the outsourcing entails a stable, long-term collaboration agreement in which the supplier becomes a strategic partner and where there are exchange relations with independent firms ( $\mathrm{Mol}$ et al., 2005; Quelin \& Duhamel, 2003), (b) the type of activity or service that can be outsourced, i.e. activities and services that are non-strategic for the firm (Quinn \& Hilmer, 1994) and (c) outsourcing is an action that transfers planning, responsibility, knowledge and administration of activities through contracts (McCarthy \& Anagnostou, 2004).

This definition has three important characteristics. Firstly, it states that outsourcing has to be a strategic decision that forms part of the firm's strategy and aimed at the pursuit and maintenance of competitive advantage. Secondly, it considers the firm must be able to identify which activities or business processes are candidates for outsourcing and developed by suppliers whose capabilities and skills are superior to those of firm. That means outsourcing decisions are relate to the firm's resources and capabilities. Thirdly, it includes the concept of business processes, whereby resources can only be a source of competitive advantage if they exploited through it (Ray et al., 2004;

Table 1. Different Definitions of Outsourcing

\begin{tabular}{|c|c|}
\hline Author/s (year) & Concept of outsourcing \\
\hline $\begin{array}{l}\text { Gilley and Rasheed } \\
\text { (2000) }\end{array}$ & $\begin{array}{l}\text { It is the substitution of activities performed in house by } \\
\text { acquiring them externally, although the firm has the } \\
\text { necessary management and financial capabilities to } \\
\text { develop them internally. It is also an abstention from } \\
\text { performing activities in house. }\end{array}$ \\
\hline Campos (2001) & $\begin{array}{l}\text { It consists of contracting an external supplier to perform } \\
\text { a task previously executed by the organization itself, } \\
\text { and may also even involve new activities. }\end{array}$ \\
\hline Bailey et al., (2002) & $\begin{array}{l}\text { Handling over some or all of that particular activity and } \\
\text { related services to a third party management, for the } \\
\text { required result. }\end{array}$ \\
\hline $\begin{array}{l}\text { Quelin and Duhamel } \\
\text { (2003) }\end{array}$ & $\begin{array}{l}\text { The operation of shifting a transaction previously } \\
\text { governed internally to an external supplier through a } \\
\text { long term contract, and involving the transfer to the } \\
\text { vendor. }\end{array}$ \\
\hline $\begin{array}{l}\text { McCarthy and } \\
\text { Anagnostou (2004) }\end{array}$ & $\begin{array}{l}\text { Not only consist of purchasing products or services from } \\
\text { external resources, but also transfers the responsibility } \\
\text { for business functions and often the associated } \\
\text { knowledge (tacit and codified) to the external } \\
\text { organization. }\end{array}$ \\
\hline Mol et al., (2005) & $\begin{array}{l}\text { The procurement of supplies from legally independent } \\
\text { entities (suppliers) }\end{array}$ \\
\hline
\end{tabular}

(Source: Adopted from Espino-Rodriguez \& Padron-Robaina (2006), p51) 
Stalk et al., 1992). Therefore, outsourcing is a strategic decision that entails the external contracting of determined non-strategic activities or business processes necessary for the manufacture of goods and services by means of agreements with higher capability firms to undertake those activities, with the aim of improving competitive advantage.

\subsection{Propensity to Outsource and Performance}

The literature review suggests dividing the discussions into two categories according to the objectives: firstly, study the propensity to outsource and secondly study the relationship between the decision to outsource and organizational performance. The first analysis analyze the level of outsourcing according to moderating variables such as the type of resource, the environment, strategic orientation, the suppliers' capabilities (Argyres, 1996; Aubert, 2004; Leiblein \& Miller, 2003; Quinn \& Hilmer, 1994). In a conceptual-type work, Quinn \& Hilmer (1994) see the suitability of developing internally the activities that comprise the core activities, and in every case advise that their outsourcing been undertaken in a framework of strategic alliances with the aim of reducing the vulnerability of the organization. Argyres (1996) shows that organizations tend to outsource when the suppliers have superior capability, and the organization does not accept the short-term cost of in house development with the aim of developing the necessary capabilities internally. Leiblein \& Miller (2003) conclude that specific assets and uncertain demand increase the danger of exchange and so decrease the probability of outsourcing activities.

The second analysis reveals the use of specific assets and other variables to determine the relationship between outsourcing and the performance of the activity and/or organization (Gilley \& Rasheed, 2000; Klaas, 2003; Murray et al., 1995; Poppo \& Zenger, 1998; Teng et al., 1995). Teng et al., (1995) conclude that the discrepancies in the perception of the outcomes (i.e. cost, the quality of the activities and financial performance) are positively relating to the propensity to outsource. Murray et al., (1995) identifies a negative relationship between outsourcing and organizational performance as the asset specifically and innovations in products and processes increase. However, there is also negative relationship between outsourcing and organizational performance when the bargaining power of supplier increase.

Bae et al., (2010) recognize that an organization with quality and cost pressures and operational strategies may arrive at different outsourcing solutions based on competitor quality strategy traits. They have developed a three-stage game-theoretic oligopolistic model based on the differentiated product strategy and integrating quality expectations of the market. The results show that these decision factors are sensitive to market expectations and quality performance of competitors. Poppo and Zenger (1998) shows in their findings the negative relationship between the specificity of resources and activity performance when the business process is outsourced. The work of Gilley and Rasheed (2000) focuses on the analysis of the impact of outsourcing an organizational performance using the competitive strategy as moderating variable, and concludes that the impact is positive in the case of a cost relationship strategy and negative in that of a differentiation strategy. Furthermore, those authors classify outsourcing into core outsourcing and peripheral outsourcing, depending on how important the manager considers the principle activities are for increase sales and profitability.

Apart from these two groups of works, the contribution of Mclvor (2000) has also been included because he analyzed outsourcing in the perspective of core competency, resources and capabilities. Mclvor (2000) proposes a theoretical framework that integrates the elements of value chain, the concept of core competences and the selection of suppliers, which are key aspects that should guide the outsourcing decision.

\subsection{Outsourcing in the Manufacturing Industry}

Schoenherr (2010) encourages compare and contrast outsourcing decisions and practices by organizations in different countries. In Malaysia, the demand for outsourcing was not only from global multi-national companies but also from local companies. Among the local companies, Bumiputra-Commerce Bank (BCB) was the first bank to outsource its IT function in late 2002 to Electronic Data System Corp. Subsequently, Maybank follows the footstep in 
outsourcing its IT function in 2003 to Computer Sciences Corporation group. SMT Industries also outsource its IT function to Sun Network and Human Resource Management to Human Resource Consultancy in Penang. The demand of the outsourcing has driven by the fact that companies could access a more reliable infrastructure that could ensure smooth core business operations at lower costs and flexibility. As Malaysia ranked the third (3) most attractive outsourcing locations in the world, Penang and Kulim Hi-Tech Park could be an advantage of this fact by attracting quality operators to the state. In addition, the government decision in constructing the second bridge connecting the island and the mainland to improve the efficient and effective way of transportation to the locals would also help Penang as a strategic location for outsourcing niche businesses. The competitive tax regimes and customized incentive would also be a pull factor for foreign outsourcing investors.

\subsection{Outsourcing Planning and Process}

Deciding to outsource some internal functions to external provider is a difficult task. Objectives and goals need to well established, a structured vendor selection process has to be developed. All the terms and conditions have to spell out clearly in a contract including controls and measurement systems. A smooth co-ordination of transition has to manage well to avoid any delay or failure. A proper planning process was absolute necessary to ensure smooth transition and good team alignment in order to accomplish successful outsourcing strategy. Some of these activities exhibit high within-stage activity independence and/or high between-stage activity interdependence. For instance, within the project planning stage, the focal firm (i.e., the owner of the project) may outsource to a contractor the activity of providing the feasibility and cost estimate of building a facility, given the owner's specification. This information will influence an organization's planning about whether to keep or change specifications and which specialist contractors have solicited to join in on the project. Within the design stage, contractors with various design specializations (e.g. structural, electrical, hydraulic and others) work simultaneously but separately on their own design activities.
Between-stage activity interdependence refers to the level of interdependence between activities performed during different project stages. For instance, many decisions that affect an entire project, such as its scope and hired contractors have made during the project planning stages, which suggests that planning activities have considerable influence over the content and quality of activities performed in all subsequent stages, including design and construction. More importantly, the quality of work in the planning stage is difficult to judge until work in the later stages of a project unfolds, such as during the construction stage, when plans are implemented and tested by events endogenous (e.g. conflicts among contractors) and exogenous to a project (e.g. bad weather and other natural disasters). Thus, planning activities have high between-stage interdependence with activities in later project stages. The high between-stage interdependence and the subsequent high information processing demand in outsourcing projects, put high pressure on an organization to run project activities in house (Whitten \& Leidner, 2006). However, for most capital construction projects or those firms often lack of requisite specialists in house, inefficient or infeasible to employ them making outsourcing as an alternative to resolve the problem.

\subsection{Decision Factors}

Decision areas in manufacturing strategy literature refer to constituents or sub-systems of a production system (Choudhari et al., 2010). It comprises of production planning and control, organization structure and control, sourcing, process technology, facilities and human resources (Miltenburg, 2005). Miltenburg (2005) describes that the settings or choices made in each decision area decides the capability of an organization in order to achieve competitive advantage. Hayes \& Wheelwright (1984) have classified manufacturing strategic decisions areas into two groups: structural and infrastructural. Both the groups are equally important to manufacturers and are dependent on each other to be successful in the market. This study would assess the relationship between the decision factors and the outsourcing decision results. The conventional approach to the creation of resources has centered on the lack of firm resources and capabilities. The firm has to decide between developing resources internally and acquiring them externally. Therefore, in order to 
exploit the combination of resources and capabilities existing in the form and to develop a strategy leading to competitive advantages, it may be necessary for the firm to acquire complementary resources from outside, and therefore an organization must not be limited to exploiting its own stock of resources and capabilities (Teng et al, 1995). Generally any lack of resources can be made up by purchases or strategic alliances, and outsourcing is one way of complementing the firm's resources and capabilities by helping to improve the firm's strategy to make better use of its capabilities when faced with external opportunities.

\subsubsection{Reduce In Operating Cost}

Williamson (1974) used operating cost as a starting assumption from traditional economic theory but not explicitly measured in most transaction cost economics (TCE) based study of outsourcing. Therefore, instead of confounding scale economies with other factors, we consider the cost advantage or cost saving from outsourcing a project verses produce internally. Cost advantage has defined as the expected overall cost saving gained from outsourcing a project instead of pursuing it internally. This conceptualization allows us to examine the cost advantage or reduce in operating cost by outsourcing. There are three areas being measure would be the capital investment, overhead and fixed cost as well as space.

\subsubsection{Reduce In Capital Investment}

How would the outsourcing help in reducing the capital investment such as equipments, building and land used in operating activities? Outsourcing the non-core operation functions would save some portion of the capital investment and used the investment into the core business that can generate more revenues to the companies. The saved fund could also used on researching and generating new market segment development (Williamson, 1974). This lead to my first hypothesis:

H1a - Reducing in capital investment positively determines outsourcing decision

\subsubsection{Reduce in Overhead and Fixed Cost}

The current economy recession has forced many people out of work. Outsourcing the non-core business function to external provider would reduced the number of headcounts or employees, and shift the core employees to focus on the core functions. Overall, the greater the perceived reduce in overhead and fixed cost by outsourcing a project, the higher the likelihood the companies in northern region of Malaysia will choose to outsource the project. This lead to my second hypothesis:

$H 1 b$-Reducing in overhead and fixed cost positively determine outsourcing decision

\subsubsection{Space Constraint}

Space was a measure of the extent on how outsourcing would help to reduce space consumption, flexibility for core business use, capacity expansion to generate new revenues or cash infusion to reduce operating cost. As project complexity increase, it will lead the companies in northern region of Malaysia will be more likely to outsource the process. This lead to my third hypothesis:

\section{H1c - Space constraint positively determines outsourcing decision}

\subsubsection{New Product Development}

Outsourcing activity would divert the resources to support the core business function and focus on new product development as well as explore new market. By shifting the resources to focus on core business and new product development, would significantly produce a tremendous impact to the companies in exploring new market segment and reap new customers to boost the revenue profitably. It also increased the shareholder values. Therefore, the higher chance in focusing on new product development and explore to new market segment will lead the companies will choose to outsource the non-core functions. This lead to my forth hypothesis:

H2a - Focusing on new product development and explore new market segment positively determine outsourcing decision

\subsubsection{Unavailability of Internal Resources and Technology}

Knowledge as a key resource that guides in managerial decision making. According to the theoretical perspective, firms viewed as distributed repositories of tacit and explicit knowledge whose 
heterogeneous knowledge bases are they key determinants of sustained competitive advantages. Therefore, outsourcing arrangement serves as a vehicle for utilizing vendors' complementary skills and expertise. Firstly, focus on whether the company has the necessary technical knowledge for successfully accomplishing a project; the second on whether the company has the latest and sophisticated technology during the new product development process. The final focuses on whether the company has the intensity to growth in term of space and capacity.

\subsubsection{Lack of technical expertise}

The organization will retain in-house the operations for which it has a higher capability, with the result of efficient production (Argyres, 1996). The operations for which a firm does not have a higher capability or technical expertise would be outsourced. As Argyres (1996) states that organizations outsource what they do not know how to do and develop in house on what they do better than the suppliers do. Therefore, lack of internal technical expertise and infrastructure will lead the company in northern region of Malaysia to outsource his project to external provider. This also leads to my next hypothesis:

H3a - Lack of technical expert and support infrastructure positively determine outsourcing decision

\subsubsection{Explore in latest and high technology}

Outsourcing has implication for strategic management. In particular, it poses challenges to the company to explore and expose to the latest and high technology equipments at the vendor's premises. Old and low efficiency technology equipments make the company more difficult to perform a high quality product, unable to access to the new product development and hard to fulfill the customer's upward demand in sudden. Therefore, the lower the client's technical equipments in house, the higher the chances of the company to outsource to the external provider. This lead to next hypotheses:

H3b - Latest and high efficiency technology positively determine outsourcing decision

\subsubsection{Intensity to Growth}

Intensity to growth is one of the objectives of any company to success in their business platform. Unfortunately, production and space limitation would be a major constraint for any expansion. Outsourcing non-core business activities would create space and capacity flexibility to support the core business function or customer's upside demand. If the company's outsource the non-core business in bulk volume, it could help the company in cost saving by negotiating for lower operating cost. Such exercise could benefit for both companies. This lead to my next hypothesis:

\section{H3c - Company's intensity to growth positively determines outsourcing decision}

\section{Research Model}

Based on the above discussion, the research model for this paper depicted in Figure 1.

Figure 1. The Research Framework

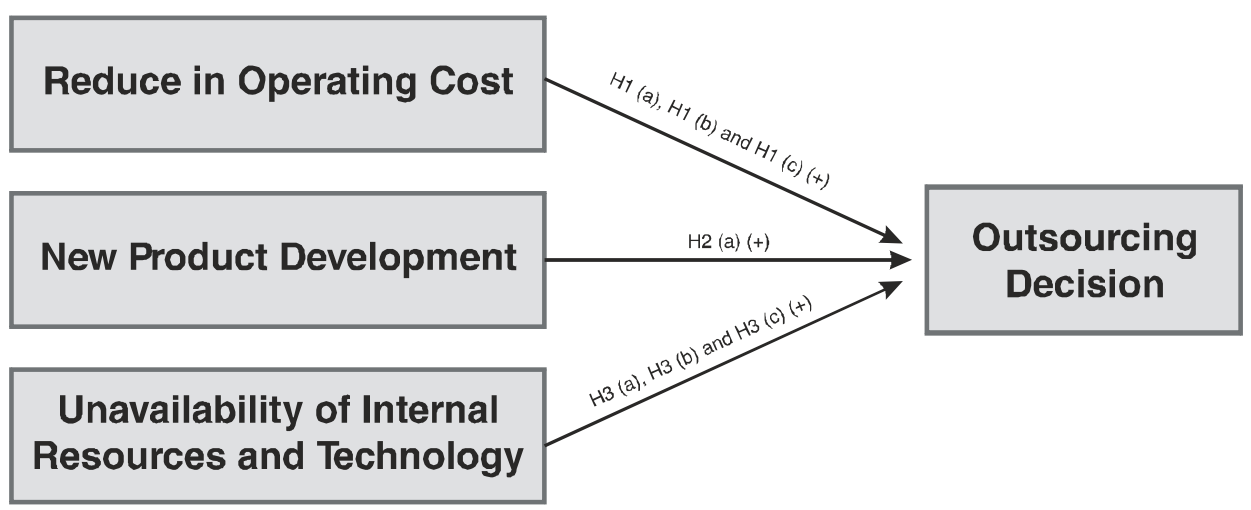




\section{Methodology}

This study is a quantitative research and questionnaire used to collect data for statistical research analysis. A hundred (100) questionnaires had distributed to Managing Director, Procurement Manager, Operation Manager, Engineer and Buyer of the companies in northern region of Malaysia. Data collection from respondents was used SPSS (Statistical Package for Social Science) software to evaluate the factors that influencing outsourcing decision in manufacturing industry of northern region Malaysia. Questionnaire survey form was send by the researcher to few companies as a pilot study, which required the respondents to feedback on their understanding to the questions. The objective of the pilot study is to understand the relevancy of the questions, difficulty to answer the questions, to understand the quality of the questions and the question appropriateness. In view of the time constraint, the respondents are required to return within three (3) days from the date of delivery.

\subsection{Population and Sampling}

The source of getting the population was from FMM directory, labor department, friends and internet. The population is all the various manufacturing industries in northern region of Malaysia and the researcher only selected a hundred (100) respondents targeted were the working adults from multinational company (MNC) such as Motorola, Intel, Daewoo, Celestica, Flextronics, Toshiba, Matsushita, Hitachi, Yamaha and few SME companies. A hundred questionnaires have distributed to the selected respondents via electronic mail (e-mail) and hardcarry. This non-probability sampling has selected due to (1) cheap, (2) greater speed of data collection, (3) flexibility, and (4) availability of population elements. Cost and time considerations influence decision about the size, type of sample and data collection method. Almost all studies have some budgetary constraint, and this is the reason encourage the researcher to choose a non-probability sample.

The analysis of the independent factors that lead the manufacturing industry in northern region of Malaysia has likelihood to choose "outsourcing" as a strategic tool to solve their problems. Therefore, a candidate selected to serve as respondent to represent each company. These respondents are selected base on the criteria below:-

a) They are either the decision maker, managing director and senior management of the department

b) Some companies allow the purchasing manager, finance and admin manager or senior procurement executive to make the decision.

c) All respondents have more than five years working experience in the manufacturing industry.

The respondents are expected to respond within two (2) weeks and questionnaires were distributed through electronic mail or hand-carry.

\subsection{Data Collection Method}

An official letter has written to a hundred selected companies for this research project. In the letter, the research briefly explained the objective of the research, so that the respondents understood the purpose of the survey. Prior to the mass distribution of the survey, a pilot survey of the questionnaire conducted to test the clarity of the questions from five different companies. The respondents well understood the questionnaires and there was no further amendment required. These five (5) respondents feedback were included in the overall data collection. The questionnaires had distributed through hard copies (by hand) and electronic mail (email) to the targeted respondents from companies to ensure wide coverage of different manufacturing industry in northern region of Malaysia. A hundred (100) questionnaires were distributed and the respondents given two (2) weeks to respond to the researcher to complete the survey. Continuous effort has made to follow up on the survey feedback to improve the response rate.

\subsection{Measurement}

The primary variable of interest would be the outsourcing decision by the manufacturing industry in northern region of Malaysia. This dependent variable survey questions had developed to evaluate the respondents that have experienced in the manufacturing industry and have the power influencing or making decision if the outsourcing 
would be the decision of choice based on the influencing factors.

The four independent variables would be Reduce Operating Cost (Williamson, 1975), Focus on New Product Development, Unavailability of Internal Resources and Technology as well as Management Competency (Boyatzis, 1982) requires during outsourcing activities. A hundred questionnaires have distributed to the selected companies via email or hand-carry to them. The respondents have given two weeks to respond to the researcher by returning the questionnaire. Twelve (12) hypotheses have generated based on four independent factors as mentioned below (Table 2). It provides an overview of how each of the four (4) independent factors influencing the manager outsourcing decision and the characteristic derived from the factors. It shows the expected influence of each factor.

In the questionnaire, the respondents are required to indicate whether they strongly agree, agree, neutral, disagree or strongly disagree based on their perception and understanding. The variables have measured ranging from scale 1 to 5 as shown below:

$\begin{array}{lll}\text { Strongly Agree } & = & 1 \\ \text { Agree } & =2 \\ \text { Neutral } & =3 \\ \text { Disagree } & =4 \\ \text { Strongly Disagree } & =5\end{array}$

All information or data for analysis have recorded manually. Combinations of these characteristics of classification will measure using nominal and ordinal data. The respondents evaluate each characteristic derived from the independent factors; this is a nominal measurement. Then the respondents ranks each independent factors from strongly agree to strongly disagree; this is an ordinal measurement. The Likert scale developed by Rensis Likert is the most frequently used variation of the summated rating scale. The respondent is asked to agree or disagree with each statement. Each response is given a numerical score to reflect it's agree of attitudinal favorableness, and the scores may be summed to measure the respondent's overall attitude toward outsourcing.

\section{Findings}

\subsection{Descriptive Statistics}

The sampling method has based on non-probability convenience sampling approach. Questionnaires had distributed to various manufacturing industries in northern region of Malaysia. Seventy (70) questionnaires have been collected back from the respondents and all of them are from the manufacturing industry in Kedah and Penang. This result has made up of $70 \%$ response rate. In summary, the sample population of demographic data shows that the data quite evenly distributed to the manufacturing industry, with different segment of duration of company established and size of the organization.

\subsection{Reliability Analysis}

Internal consistency reliability measures the reliability of a summated scale and refers to the statements of the questionnaire represent the variable of interest. A popular approach to assess the reliability is using the coefficient alpha or Cronbach's Alpha analysis. Cronbach's alpha is a reliability coefficient that indicates how well the items in a set are positively correlating to one another. Cronbach Alpha is computed in terms of the average intercorrelations among the items measuring the concept. The closer Cronbach's alpha is to 1, the higher the internal consistency reliability. The coefficient varies from 0 to 1 and a value is greater than 0.6 indicates

Table 2. Summary of the Constructs and Hypotheses

\begin{tabular}{|c|c|c|c|}
\hline $\begin{array}{l}\text { Independent } \\
\text { Factors }\end{array}$ & Constructs & Hypothesis & $\begin{array}{l}\text { Expected } \\
\text { Influence }\end{array}$ \\
\hline $\begin{array}{l}\text { Reduce } \\
\text { Operating } \\
\text { Cost }\end{array}$ & $\begin{array}{l}\text { a) Reduce in capital investment } \\
\text { b) Reduce in fixed and variable } \\
\text { cost } \\
\text { c) Space constraint }\end{array}$ & $\begin{array}{l}\mathrm{H} 1 \text { (a) } \\
\mathrm{H} 1 \text { (b) } \\
\mathrm{H} 1 \text { (c) }\end{array}$ & $\begin{array}{l}+ \\
+ \\
+\end{array}$ \\
\hline $\begin{array}{l}\text { New Product } \\
\text { Development }\end{array}$ & $\begin{array}{l}\text { a) Focusing in new product } \\
\text { development and explore } \\
\text { new market segment }\end{array}$ & H2(a) & + \\
\hline $\begin{array}{l}\text { Unavailability } \\
\text { of Internal } \\
\text { Resources } \\
\text { and } \\
\text { Technology }\end{array}$ & $\begin{array}{l}\text { a) Lack of technical expertise } \\
\text { and support infrastructure } \\
\text { b) Explore in latest and high } \\
\text { technology } \\
\text { c) Intensity to growth }\end{array}$ & $\begin{array}{l}\mathrm{H} 3(\mathrm{a}) \\
\mathrm{H} 3 \mathrm{~b}) \\
\mathrm{H} 3(\mathrm{c})\end{array}$ & $\begin{array}{l}+ \\
+ \\
+\end{array}$ \\
\hline
\end{tabular}


satisfactory internal consistency reliability. The Cronbach's Alpha for each of the variable had computed using SPSS for this assessment. All the variables have gone through the factor analysis or principle component analysis. The sub-variables in each independent variable are recorded and, the result shows that KMO and Bartlett's test is greater than 0.5 , which is an accepted principle component analysis.

\subsection{Determinants of Outsourcing Decisions}

The linear regression analysis has used to analyze the relationship between the dependent variable and the independent variables. The key assumption is that the relationship between the dependent variable and independent variables is linear. This study shows that the dependent variable is outsourcing decision and the independent variables are capital investment, overhead and fixed cost, space constraint , focus on new product development, lack of technical expert and support infrastructure, latest technology and high efficiency, intensity to growth, leadership and communication. Table 3.0 shows the results of the linear regression analysis.

From the results of the regression analysis, the $\mathrm{R}$ square of the model of this study is 0.264 . This indicates that this model can explain only $26.4 \%$ of the outsourcing decision variability. The $\mathrm{R}$ is 0.514 , which indicates a high level of linearity within the model, which fit to the key assumption of the linear regression analysis. The Durbin-Watson is 2.077 indicating no auto correlation problem in the data.

\subsubsection{Relationship between Reduce Operating Cost and Outsourcing Decision}

There were three (3) factors in Reduce operating Cost such as capital investment, overhead and fixed cost as well as space constraint as shown below:

\section{H1a-Reducing in capital investment positively determines outsourcing decision}

\section{H1b - Reducing in overhead and fixed cost positively determine outsourcing decision}

\section{H1c - Space constraint positively determines outsourcing decision}

The analysis result shown that $\mathrm{H} 1 \mathrm{~b}$ and $\mathrm{H} 1 \mathrm{c}$ have no significant impact to the outsourcing decision because the sig. thigher than 0.05 significant effect level. However, reducing in capital investment (H1a) positively influence in outsourcing decision because the significant effect of 0.025 , which was below the $5 \%$ significant level. Thus, the hypotheses H1a has accepted.

\subsubsection{Relationship between New Product Development and Outsourcing Decision}

This variable has one predictor, which was focus on new product development and explore new market segment.

H2a - Focusing on new product development and explore new market segment positively determine outsourcing decision.

Table 3. Results from Linear Regression Analysis

\begin{tabular}{|c|c|c|c|c|c|c|}
\hline \multirow{2}{*}{ Model } & \multicolumn{2}{|c|}{ Unstandardized Coefficients } & \multirow{2}{*}{$\begin{array}{c}\begin{array}{c}\text { Standardized } \\
\text { Coefficients }\end{array} \\
\text { Beta }\end{array}$} & \multirow{2}{*}{$t$} & \multirow{2}{*}{ Sig. } & \multirow{2}{*}{$\begin{array}{l}\text { Sig. F } \\
\text { Change }\end{array}$} \\
\hline & B & Std.Error & & & & \\
\hline 1 (Constant) & 2.437 & 0.926 & & 2.632 & 0.011 & $0.022^{*}$ \\
\hline Capital Investment & 0.682 & 0.297 & 0.364 & 2.297 & $0.025^{\star}$ & \\
\hline Overhead \& Fixed Cost & 0.184 & 0.272 & 0.115 & 0.678 & 0.500 & \\
\hline Space Constraint & -0.414 & 0.437 & -0.187 & -0.948 & 0.347 & \\
\hline New Product Development & 0.334 & 0.323 & 0.163 & 1.034 & 0.305 & \\
\hline $\begin{array}{l}\text { Lack of Technical Expert } \\
\text { and Support Infrastructure }\end{array}$ & -0.013 & 0.235 & -0.006 & -0.055 & 0.956 & \\
\hline $\begin{array}{l}\text { Latest Technology and } \\
\text { High Efficiency }\end{array}$ & 0.712 & 0.263 & 0.331 & 2.707 & $0.009^{\star}$ & \\
\hline Intensity to Growth & 0.479 & 0.252 & -0.226 & -1.899 & 0.062 & \\
\hline
\end{tabular}


The result has shown that this predictor has no significant impact (0.305) to the outsourcing decision because it was higher than 0.05 significant effect levels.

\subsubsection{Relationship between Unavailability of Internal Resources and Outsourcing Decision}

This variable has three (3) predictors to be tested. There were (a) lack of technical expert and support infrastructure, (b) latest and high efficiency technology and (c) intensity to growth.

H3a - Lack of internal technical expert and support infrastructure positively determine outsourcing decision

$H 3 b$ - Latest and high efficiency technology positively determine outsourcing decision.

H3c-Company's intensity to growth positively determines outsourcing decision

These two H3a and $\mathrm{H} 3 \mathrm{c}$ predictors had found no significant impact on outsourcing decision based on the result of analysis because sig. $t$ was higher than 0.05 significant effect level. Thus, the hypotheses of $\mathrm{H} 3 \mathrm{a}$ and $\mathrm{H} 3 \mathrm{c}$ had rejected. Conversely, $\mathrm{H} 3 \mathrm{~b}$ has found to have significant effect on the outsourcing decision, which at the $5 \%$ significant level. Therefore, the hypotheses H3b has accepted.

\section{Discussion and Conclusions}

The results have three important practical implications for both clients and vendors. First, outsourcing decisions are not driven predominantly by relative cost advantage of doing so. Clients must therefore better understand the best practice element of an internal cost structure before outsource a project to vendors, to avoid any unnecessary significant amounts of hidden costs occurred during outsourcing. Second, technology knowledge, skills and attitudes differences influence outsourcing decisions. For vendors, this suggests the need to convince and demonstrate how their technical expertise exceeds that of prospective client. Finally, in projects of high strategic importance, client's willingness to outsource is influence by their ability to specify requirements and to keep them stable over the course of a project. Vendors with well-developed capabilities for requirement analysis and management might therefore enjoy an advantage in attracting contract for strategic applications development projects.

\subsection{Limitations of the Study}

The respondents are from the selected manufacturing industry in northern region of Malaysia. Total 70 companies been selected to collect the quantitative response and sampling data. There were several limitations to this research study as below:-

a) Cost and time might influence about the size, type of sampling and data collection method. The budgetary constraint will lead the researcher to choose a non-probability sample in this study.

b) The interpretations of the questionnaires are subject to the understanding of the respondents, the different manufacturing experience and exposure might influence the respondents on answering the questions.

c) The survey has conducted based on different market segment in the manufacturing industry and various levels of employees as the respondents. It may not be accurate and good representing of support the factors influencing the outsourcing decision.

d) The constraints on how many attributes could simultaneously be included in this analysis limited us to just twelve predictors from reducing operating cost, new product development, unavailability of internal resource and technology as well as management competency. This also constrained the breadth of some measures such as lack of coordination and control cost, which was measured on the somewhat simplistically as the absence of the client-vendor trust and teamwork.

\subsection{Suggestion for Further Research}

Based upon the limitations, the researcher would like to provide some suggestions for future research into outsourcing decision in relation to capital investment as a factor of influencing outsourcing decision. First, studies on capital investment as a factor should cover a large sample in Malaysia not only northern region of Malaysia to evaluate the consistency of the responses across the country. With the sufficient capital investment, the research may conduct better 
sampling method and interview the respondents personally. This would help to obtain more data, which would lead to applicable and accurate results. Secondly, Questionnaires design has to be well defined and restructured to ensure the respondents understand the questions in order to provide accurate feedback. Third, the researcher would suggest that survey has conducted based on similar business market segment in the manufacturing industry and limit to management level as the respondents. Feedback on the similar manufacturing industry will produce better analysis results.

Lastly, lack of coordination and control cost can mitigated through a variety of features of the outsourcing contracts. Similarly, a shared identity and culture can also help create shared understanding and build a good business partnership beside the requirements. Future work should examine such less salient variables identified by these theories that have not considered in our analysis. Future research should also incorporate and analyze other variable such as sharing risks, accelerating re-engineering and cash infusion due to outsourcing. It would be interesting also to include the moderator for the future research such as top management support.

\subsection{Conclusion}

This research was motivated by the scarcity of a systematic comparison of the various theoretical perspectives that have been invoked to examine the principal findings of research on outsourcing, four independent variables such as reduce operating cost, focus on new product development, unavailability of internal resource and technology as well as management competency. Our primary objectives were therefore to understand whether there is a cost implication after the outsourcing decision, and to analyze the relationship of the above-mentioned factors that influencing in considering the outsourcing decision. We also explored how these four independent variables complement and contradict in their predictors for some factors.

We tested the model using regression analysis and the results showed only two out of twelve predictors supported the hypotheses and have positive as well as significant influence in outsourcing decision. This study has given some insight views and usefulness of the research data to the manufacturing industries that cost is not the only and main factor to determine outsourcing decision. It is necessary to validate the conceptual framework to the outsourcing decision in different economic sectors and geographical zone that helps to forecast the types of activities that need to outsourcing and in demand by the companies. In order to consider outsourcing as one management strategy to keep the business running, managers need to study carefully for better understanding the position of manufacturing firms in dealing with outsourcing. The government agencies should understand the realities in Malaysia before making any policies, which will be impact the profit of manufacturing firms.

\section{References}

Argyres, N. (1996), Evidence on the role of firm capabilities in vertical integration decisions, Strategic Management Journal, 17, pp. 129 - 150.

Aubert, B. A., Rivard, S., and Party, M. (2004), A transaction cost of IT outsourcing. Information \& Management, 41, pp. 921-932.

Bailey, W., Masson, R., and Raeside, R. (2002), Outsourcing in Edinburgh and the Lothians, European Journal of Purchasing \& Supply Management, 8, pp. 83-95.

Bae, S. H., Yoo, C. S., and Sarkis, J. (2010), Outsourcing with quality competition: Insights from a three-stage game-theoretic model, International Journal of Production Research, 48, pp. 327-342.

Boyatzis, R. E. (1982), The Competent Manager. Wiley, New York.

Choudhari, S. C., Adil, G. K., and Anathakumar, U. (2010), Congruence of manufacturing decision areas in a production system: A research framework, International Journal of Production Research, 48, pp. 5963-5989.

Espino-Rodriguez, T. F., and Padron-Robaina, V. (2006), A review of outsourcing from the resource-based view of the firm, International Journal of Management Reviews, 8 (1), pp. 49-70.

Gilley, K. M. and Rasheed, A. (2000), Making more by doing less: analysis of outsourcing and its effects on firm performance, Journal of Management, 26, pp. 763790.

Hayes, R. H., and Wheelwright, S. C. (1984), Restoring our competitive edge: Competing through manufacturing, New York, John Wiley and Sons.

Joskow, P. L. (1998), Asset specificity and the structure of vertical relationships: empirical evidence, Journal of Law, Economics and organizations, 4, pp. 95-117. 
Leiblein, M. J., and Miller, D. J. (2003), An empirical examination of transaction and firm level influences on the vertical boundaries if the firm, Strategic Management Journal, 24, pp. 839-859.

Lyons, B. (1995), Specific investment, economies of scale, and the make-or-buy decision: a test of transaction cost theory, Journal of Economic Behavior and Organization, 26, pp. 431-443.

Masten, S. (1984), The organization of production: Evidence from the aerospace industry, Journal of Law and Economics, 27, pp. 403-417.

McCarthy, L. P., and Anagnostou, A. (2004), The impact of outsourcing on the transaction cost and boundaries of manufacturing, International Journal of Production Economics, 88, pp. 61-71.

Mclvor, R. (2000), A practical framework for understanding the outsourcing process, Supply Chain Management: An International Journal, 5, pp. 22-36.

Miltenburg, J. (2005), Manufacturing strategy - how to formulate and implement a winning plan, Productivity Press, Portland.

Mol, M. J., Van Tulder, R. J. M., and Beije, P. R. (2005), Antecedents and performance consequences of international outsourcing, International Business Review, 14, pp. 599-617.

Monteverde, K., and Teece, D. J. (1982), Supplier switching costs and vertical integration in the automobile industry, Bell Journal of economics, 13, pp. 206-213.

Murray, J. Y., Kotabe, M., and Wildt, A. R. (1995), Strategic and financial implications of global sourcing strategy: a contingency analysis, Journal of International Business Studies, pp. 181-202.

Poppo, L., and Zenger, T. (1998), Testing alternative theories of the firm: transaction cost, knowledge based, and measurement explanations for make or buy decision in information services, Strategic Management Journal, 19, pp. 853-877.
Quelin, B., and Duhamel, F. (2003), Bringing together strategic outsourcing and corporate strategy: outsourcing motives and risks, European Management Journal, 21, pp. 647-661.

Quinn, J. B. (1992), Intelligent Enterprise: A Knowledge and Service Based Paradigm for Industry, The Free Press, New York.

Quinn, J. B., and Hilmer, F. G. (1994), Strategic outsourcing, Sloan Management Review, pp. 43-55.

Ray, G., Barney, J. B., and Muhanna, W. A. (2004), Capabilities, business processes and competitive advantages: choosing the dependent variable in empirical test of the resourcebased view, Strategic Management Journal, 25, pp. 23-27.

Schoenhorr, T. (2010), Outsourcing decisions in global supply chains: An exploratory multi-country survey, International Journal of Production Research, 48, pp. 343-378.

Spencer, L. M., and Spencer, S. M. (1993), Competence at Work: Models for Superior Performance, Wiley, New York.

Stalk, G., Evans, P., and Shulman, L. (1992), Competing on capabilities: the new rules of corporate strategy, Harvard Business Review, 70, pp. 57-68.

Teng, J., Cheon, M., and Grover, V. (1995), Decisions to outsource Information systems functions : testing a strategy-theorydiscrepancy model, Decision Sciences, 26, pp. 75-103.

Walker, G., and Weber, D. (1984), A transaction cost approach to make or buy decisions, Administrative Science Quarterly, 29, pp. 373-391.

Whitten, D., \& Leidner, D. (2006), Bringing IT back: An analysis of the decision to backsource or switch vendors, Decision Sciences, 37, pp. 605-621.

Williamson, O. E. (1974), Markets and Hierarchies: Analysis and Antitrust Implications. A study in the Economics of Organization, The Free Press, New York.

Williamson, O. E. (1975), The Economic Institutions of Capitalism, The Free Press, New York.

Williamson, O. E. (1991), Strategizing economizing and economic organization, Strategic Management Journal, 12, pp. 75-94.

Dr. Shankar Chelliah is currently affiliates with Universiti Sains Malaysia (USM), based in Penang, Malaysia. Prior becoming academician, he has fifteen years of corporate experiences by holding various positions in blue chip companies such as Motorola and Intel. Currently positioned in the section of International Business and teaching subjects relating to cross cultural management, international human resources management, and international business management. Apart from supervising students at postgraduate level, he is actively involved in consultancy services and social responsibility initiatives to key clients from the industry. His current research interests includes: (a) Policies and strategies relating to the internationalization of Small and Medium Enterprises (SMEs) and (b) Management of international operations, including corporate entrepreneurship, and survival strategies in both multinational enterprises and, small and medium enterprises. 
Ms Jenny Teoh Aui Meng, is a Senior Management staff in one of the multinational company. Graduated with a MBA (specializing in Management) at Open University Malaysia, hold a Graduate Diploma in Business Administration from Perkin Goon, Certificate in Delivering, Services and Quality Program in Singapore as well as Certificate in Negotiating, Sales, Purchase and Contract. She had more than 20 years of practical experience in both manufacturing and service industry.

Dr. Jayaraman Munusamy is currently serving Limkokwing University of Creative Technology as an Associate Professor in the Centre of Post-Graduate Studies. 